\title{
Philosophical Deficiencies East and West
}

As previously, "East" here mainly means China and not Asia generally. My reasons for this restriction are the same as they have always been. First, I have never been interested enough in Indian philosophy to learn its details, and Japanese philosophy, when it isn't deriving inspiration from German philosophy, gets much of its material and method from Chinese thought. So the limitation here is clearly of my own doing or lack of doing, but even thus limited I think there is much I can say about the major contrasts between Chinese and Western thought. Second, I hope that the contrasts I shall draw between Chinese and Western thought will allow me to propose a short general scheme of what is necessary and advisable for contemporary philosophizing (even in India and Japan), a scheme that I believe takes in a greater variety of philosophical options than has been mentioned much less systematized by other philosophers. Let's see how all that might work.

\section{1}

Some years back, in the appendix to my book The Impossibility of Perfection: Aristotle, Feminism, and the Complexities of Ethics (OUP, 2011), I wrote about some cognitive problems with the way philosophers do philosophy. The appendix was titled "Men's Philosophy, Women's Philosophy," and it sought to show or perhaps just point out some different weaknesses or

M. Slote, Between Psychology and Philosophy, Palgrave Studies in Comparative East-West Philosophy, https://doi.org/10.1007/978-3-030-22503-2_4 
deficiencies in the way women and the way men have (often or typically) dealt with philosophical issues. Care ethicists, for example, are predominantly women, and care ethicists typically pay a great deal of attention to issues of moral psychology: for example, issues about how caringness is learned or instilled and about how (via empathy) particular caring actions are engendered and undertaken. Similar attention to issues of actual psychology is paid by virtue ethicists, and most virtue ethicists are also women. Male ethicists in the Kantian tradition show much less interest in such issues, and even when they do, I think they show a much less delicate sensitivity to psychological aspects of the moral life than is shown by the care ethicists and the virtue ethicists. (I know that there are a lot of women Kantians too.)

Now someone might object that both Thomas Nagel and T. M. Scanlon do moral psychology in a robust way, and they do, they do. But Nagel in The Possibility of Altruism (in my opinion his strongest and best book) is more interested in the a priori necessary structure of practical reason(s) than in empirical/sensitive/introspectively-grounded moral psychology. ${ }^{1}$ And although Scanlon's attention to the moral life does bring in moralpsychological elements in a central way, I think his views are dictated more by a priori ethical (and also epistemological) considerations than by actual attention to how we live and experience our lives. Scanlon notably claims that we experience the appearance of reasons, when we act on the basis of practical reasons, and for the life of me I don't think I have ever experienced what Scanlon says is occurring all the time. ${ }^{2}$ When I put the clock back in the fall, I have and know I have a reason to do so, but does that reason enter my consciousness as a kind of appearance? Things can appear red to me, things can appear congruent to me, things can appear messy to me, but I don't think I have ever experienced something that can be called an apparent reason to act or the appearance of such a reason. And things are even worse for Scanlon because he regards reasons as non-natural phenomena, and this raises the familiar problem of explaining how something outside of nature-like a number or, in Scanlon's case, a reason for action-can causally affect something in nature, a human mind, in the form of an appearance of a given reason. No one has ever figured out how to make sense of this kind of causality, so this complicates even further what Scanlon wants to say about our moral psychology.

\footnotetext{
${ }^{1}$ Nagel, The Possibility of Altruism, Princeton: Princeton University Press, 1978.

${ }^{2}$ Scanlon, What We Owe to Each Other, Cambridge: Harvard University Press, 1998.
} 
I think I know what has gone wrong here with Scanlon. Aside from its frequent but arguably incoherent invocation and application of the idea of non-natural phenomena, ethical rationalism is uncomfortable with the idea of using desire, emotion, or empathy to explain why we act or act rationally in a given situation. But Scanlon thinks there has to be something (else) mental or psychological that we can know about and that gears us up toward acting rationally or irrationally, and the idea of an appearance of a reason seems to serve that purpose once all other psychological explanations have been ruled out. However, I think this idea of an appearance of a reason is just something invented to fill a gap in rationalistic theory rather than something that derives from a sensitive appreciation of what the moral life or life in general is like from the inside.

More generally, I think male philosophers are less sensitive, on the whole, to psychological nuance than women philosophers have been, but, as the appendix in my book argued, we need a high level of psychological sensitivity in order to do full justice to morality and the moral life. Of course, if Kantian rationalism is true, that may not be so, but having myself argued for a non-Kantian approach to ethics \{my earlier Chap. 2 offers a very negative "critique of pure reason" $\}$, I think I can say that conditional on the validity of such a different approach, philosophers need to be sensitive rather than obtuse about matters of moral and human psychology. Let me give you another example of how obtuse male analytic philosophers can be about issues involving sensitivity to others or sensitive introspection of one's own psychology.

In recent years, there has been a lot of talk about open-mindedness among epistemologists, especially virtue epistemologists. ${ }^{3}$ Openmindedness is said to be an epistemic virtue, alongside intellectual courage, thoroughness, and so on. But one fact about open-mindedness has been neglected by the philosophers who speak of it. Open-mindedness of the fullest kind involves an ability and willingness to see things from the point of view of those who disagree with one about particular issues, but other philosophers focusing on open-mindedness have never pointed this out. Well, all right, what is the problem? One points it out, the literature on open-mindedness takes it into account, and the discussion and exploration continue. But not so fast!

\footnotetext{
${ }^{3}$ See, for example, Linda Zagzebski, Virtues of the Mind: An Inquiry into the Nature of Virtue and the Ethical Foundations of Knowledge, NY: Cambridge University Press, 1998.
} 
When I point out the connection between open-mindedness and seeing or attempting to see things from the point of view of others (within limits-you don't need to do this with a woman who thinks she is Napoleon), philosophers don't go along with this as an interesting insight. Rather, they object, and the objectors have all been males. I am told that openmindedness only requires that one make judgments impartially or fairly with respect to available evidence, and the connection with seeing things from the standpoint of others is staunchly denied? (Some of you readers may be denying it right now.) What is going on here?

My diagnosis is very critical of those who don't see the point I was trying to make. Natch! But look, let's think about the relevant issues! To begin with, the emphasis placed on fairly dealing with evidence suggests to me that the philosophers who have objected to what I have said about open-mindedness are confusing open-mindedness with fair-mindedness and so are not being sensitive to linguistic nuance here. Fairness and openness are different concepts, and think, then, what we must mean when we use the notion of openness or open-mindedness. What are we supposing that the open-minded person is open to? Now some philosophers who speak of open-mindedness have emphasized the epistemic importance of being willing to think in new ways and accommodate new realities in one's thinking, and that is certainly a kind of openness that doesn't as such make any reference to those who do or might disagree with one. But if someone were open to new facts and theories only when no one else held them and they didn't contradict anything one currently believed, would we really call them completely or ideally open-minded? I don't think so. I think the openness involved in open-mindedness involves, at least ideally, being willing to really listen to what others who disagree with one are saying and arguing; and when a wife tells her husband that he is not really listening (to her or to what she is saying), she surely means that he should make more of an effort to see or understand where she is coming from. And to see where someone is coming from is to see things from that person's point of view. QED.

What has gone wrong here? Why do male philosophers have such a difficult time understanding the point about open-mindedness and seeing things from the other's point of view (a form of empathy)? I spoke a moment ago about a failure of linguistic sensitivity, but I think more is in play here than linguistic insensitivity. On the whole, male philosophers in the Western analytic tradition are more comfortable arguing rationally or analytically than looking inside themselves for clues about philosophical 
issues. But we should also consider what might happen if and when they did look. I wonder whether the male philosophers who deny the connection with seeing things from the other's point of view have ever had, or remember ever having, that particular experience. It is an experience I remember having myself, as, for example, I think or have thought my way into one of the chief reasons or motives for being an ethical rationalist, the desire for morality to be objectively valid, rather than merely expressive or subjective/ relative. Recent expressivists and emotivists typically defend their views without regretting or even noting the way those views go against an antecedent desire to preserve morality as something with a right to command us, with objective force or validity. Perhaps the recent expressivists and emotivists simply don't share that desire, but they ought in any case to show themselves more aware of the force it has for others and to try to argue, somehow, against such force or validity. Which they typically don't do.

But to get back to those who deny any connection between openmindedness and seeing things from the point of view of someone who disagrees with one, we might do well to consider the possibility that these philosophers just don't go through the effort of seeing things from the standpoint of others. They may lack that kind of motivation and their failure to recognize it in themselves may be due to the fact of its absence there. Then their failure to recognize it in others may be in some measure traceable to the absence of such motivation in themselves, though possibly also to their lack of sensitivity to the psychology of others. (In this case, it would be a lack of empathy for the empathy others exercise when they put themselves or receptively find themselves in others' intellectual shoes.) In the absence of all that, they say that open-mindedness is just a matter of being impartial and fair with regard to evidence, and that is my tentative explanation of why the male philosophers I am speaking of seem to see no reason whatever to connect open-mindedness with seeing things from the standpoint of others.

But let me return to the issue of whether or how male philosophers are deficient in relation to female philosophers. Yes, we have shown (I believe) that they are on the whole less sensitive to psychological nuance than women philosophers and especially care ethicists tend to be. (I am not talking about Michael Stocker and Bernard Williams.) But in addition, and this is a quite new point, male philosophers tend to be prejudiced against female philosophizing in some very unfortunate ways. In Appendix B I shall say something more specific about one of the main ways this has happened. But it is worth noting that such philosophical prejudice is part of a wider or deeper phenomenon. In In a Different Voice: Psychological 
Theory and Women's Development (Harvard U. P., 1993/1982), Carol Gilligan points out that under the historical conditions of patriarchy, people tend not to pay attention to what women and girls say-by comparison with what is said by men and boys. And, sadly, this is often as true of the attention paid by women as of the attention paid by men. Gilligan brilliantly speculates that these factors frequently lead women to lack confidence in their own ideas and aspirations and to be selfless in regard to the needs of others. Such treatment also constitutes (as I have argued in many places) a failure to respect women and girls, and the second appendix of the present book concludes what it has to say positively about social justice in relation to empathy by arguing that the lack of attention male neoKantian ethicists (most notably, Derek Parfit, Thomas Nagel, Ronald Dworkin, and T. M. Scanlon) pay to the ideas of care ethics shows, at the academic level, a similar failure or refusal to really listen to women's voices of the kind Gilligan initially made us (theoretically) aware of.

\section{2}

To get back to the explicit comparison of how well male and female philosophers do philosophy, my main point above has been that male analytic philosophers have been somewhat obtuse about issues of psychology involving nuance, introspection, or empathy-at least by comparison with female philosophers. This is a major philosophical deficiency or weakness, even if it is unevenly distributed between the (traditional) human genders. But the appendix of my book The Impossibility of Perfection wasn't as onesided as the just-offered critique might be thought to be. The book also spoke of a major intellectual or philosophical deficiency that affects or has affected women more than men. Male philosophers in the analytic tradition (and many female philosophers too) place a great emphasis on precise argumentation based on fine analytic distinction-making, and one finds much less of this among women, especially, care ethicists. My appendix noted how problematic this is or can be. Some female feminist philosophers have pointed out to me that when some male or female at a conference or a meeting devoted to care ethics makes a sharp analytic objection to some point in care ethics, they are frequently met with the criticism that they are being too analytic and, sometimes, with the further criticism that what they are saying and the way they are saying it works against feminist goals and aspirations. Their criticisms are treated almost automatically as some kind of sexism. 
This is too bad. The fact that those who have emphasized reason and argumentation so much in the past have also opposed care ethics and perhaps even feminism is no reason why women shouldn't employ the same powerful tools in favor of feminism and/or care ethics (or virtue ethics or anything else in philosophy). When I was about to publish my book The Ethics of Care and Empathy (Routledge, 2007), Carol Gilligan treated it as a major event in care ethics because here was an analytic philosopher using familiar forms of analytic argument to defend care ethics, something that previous care ethics had not really done so much of. (If you don't believe me, look at the blurb she wrote for that book.) And I am taking up Gilligan's point or point of view here. Care ethicists and women philosophers generally shouldn't shy from analytic argument and precision. This doesn't threaten their views and can even be helpful to their views as long as those views continue to show the sensitivity to psychological realities that has typically been their hallmark. But as of right now care ethics has been less interested in engaging, analytically and argumentationally, with other ethical views than I think it should be.

This relates to another problem with the way care ethics has been done. Female care ethicists have largely shied away from issues of moral semantics and from attempts to connect care ethics with issues in other areas of philosophy. None has so far published any sort of full-bodied account of what terms like "right" and "good" mean, and none, to my knowledge, has shown any interest in questions about the implications of care ethics for general issues that border the philosophy of mind such as the nature of epistemic rationality. It is as if, given the back of the hand that mainstream philosophy has given care ethics, the care ethicists are repaying the compliment by paying little or no attention to standard philosophical issues outside care ethics considered strictly in normative terms. But to consider traditional or standard philosophical questions is not-not! - to be committed to giving familiar philosophical answers. Care ethicists or those who favor care ethics need really to open up a bit in their philosophical interests. Care ethics can compete with other views in general philosophical terms if only it will let itself do that. If (as is so often said) men connect less well or willingly with other human beings than women do, women for their part may be less willing or able than men to connect the ideas they like with other or further ideas. So if men need to be more psychologically sensitive, women may need to think in more systematic terms than has been typical with them. 
In any event, the failure to take advantage of and become steeped in analytic argumentation and distinction-making does in my opinion represent an important cognitive/philosophical deficiency or inadequacy on the part of many of the women philosophers who have been so excellent at moral psychology. Why can't philosophy go forward in theoretical and even synoptic fashion without the typical male failure to respond or react sensitively to psychological realities and without the frequent female failure to master and exercise the arts of analytic thinking? Why not indeed?

However, my last complaint, the complaint about the lack of analytic thinking typical of much female philosophical thinking or at least the thinking of care ethicists, reaches out beyond the distinction between males and females. In recent years I have been exploring the connections between Western virtue ethics and Confucianism, and I believe and have already argued earlier in this book that (we) Westerners have a great great deal to learn from the traditions of Chinese thought. But just as I have claimed for the case of women and care ethicists in particular, I think that Chinese philosophy as a whole would do well or better to place more emphasis on the development of analytic skills than it previously has. That may well mean many Chinese philosophers' acquiring a better knowledge of Anglophone Western philosophy and sending more of their undergraduate students for graduate training in American, British, Australian, and so on, philosophy departments, which latter is in fact happening more and more these days. But one has to hope that the Chinese students who get trained in analytically oriented departments aren't also trained into believing that their own traditions are irrelevant to present-day philosophical issues and concerns. As I say and have argued earlier, we have a great deal to learn from China, and I hope that Chinese students will be able to appreciate that even after they have got their doctorates from Western universities. Still, what I have said classes traditional Chinese thought with female-dominated care ethics in one respect-as typically failing to show some of the analytic skills and precise thinking that are needed for the fully satisfactory doing of philosophy. But I am not yet done with the philosophical deficiencies of philosophers.

\section{3}

Philosophers typically take up some approach or position early in their careers and continue to defend it (and elaborate it) for the rest of their careers. What Kantian ethicist has ever renounced Kantianism for Aristotelian virtue ethics or care ethics, and what Aristotelian or care ethi- 
cist has later given up their view in favor of a Kantian approach to ethics? Similarly, what free-will compatibilist has ever become convinced of libertarianism or vice versa? I don't know of any examples here, and these are fields I have long been familiar with; and even if some cases have escaped my notice or yours, the lack of basic change I am ascribing to philosophers as a class is a rather noteworthy fact about them-even if it is something that, as far as I know, has escaped everyone's attention and never been focused on in the philosophical literature. (Even if someone has noticed or mentioned this, it has not been broadly brought to the attention of philosophers.)

Unfortunately, I think there is a ready and all-too-obvious explanation of why this is the case with philosophers. Virtue epistemologists are always talking about the importance of open-mindedness as an epistemic virtue, but in fact philosophers (like a lot of other academics) don't show much sign of actually being open-minded in regard to views they initially disagree with. This is another besetting intellectual deficiency or defect of philosophers, and though I know this is a hard pill to swallow, I am hereby inviting philosophers to swallow it. Think about it! Are we really openminded about other people's disagreeing views once we have committed ourselves or find ourselves committed to some particular philosophical tradition or approach? In graduate school we often have to read everyone's views on particular topics, but once we have our doctorates and have sided with a particular tradition, do we really take the time to read and seriously engage with other traditions? How many care ethicists read the most recent important book in or on Kantian ethics, and how many Kantians bother to read seriously in the literature of care ethics? Very, very few!

The practitioners of philosophy are not open-minded; they lack that widely regarded intellectual/epistemic virtue, though those who proclaim the virtue status of that trait don't seem to realize how lacking they and all of us are in that valuable trait. (I expand on this theme in the first Appendix to this book.) So this is another sin or intellectual weakness of philosophers, but not necessarily, as far as anything I have so far argued, a problem with philosophy itself. Ideally, philosophers would think analytically

\footnotetext{
${ }^{4}$ Bertrand Russell and Hilary Putnam are notable exceptions to my claim that philosophers choose a basic position and then stick with it throughout their careers. But to change basic positions as often as Russell and Putnam did seems to be flighty rather than open-minded, so what I am saying in the main text can stand (qualified as I have just qualified it).
} 
and with psychological and linguistic sensitivity about philosophical issues while at the while being open-minded toward views they initially disagree with. But perhaps we human philosophers aren't really capable of doing all that philosophy itself, if I may put things that way, would ask of us.

\section{4}

A major objection to what I have been saying may at this point have occurred to readers. I have spoken of rigid closed-mindedness as a problem generally for philosophers, but is it as much a problem for Chinese philosophers as it is for Western (especially analytic) philosophers? I think not.

To be open-minded is to be receptive to the ideas of others even if they initially disagree with one's own, and in my book From Enlightenment to Receptivity: Rethinking Our Values (OUP, 2013) I argued that Western philosophy has largely either ignored or been hostile to the idea, the value, of receptivity. ${ }^{5}$ The book also made the point that Chinese thought is not like that. Let me illustrate this difference by reference to two roughly contemporaneous philosophers in China and the West.

Mencius in the Mencius (4B28) tells us something very interesting, important, and (judging by my own reaction) striking about how we should react when someone hurts or harms us. Rather than retaliate or immediately feel anger and indignation/resentment, Mengzi tells us that we should first ask ourselves what we might have done to provoke the person who has hurt us and/or how we may have hurt them previously. To recommend such a reaction is to recommend in effect that we be receptive to the other's point of view even when they have hurt or harmed us. Mengzi doesn't use a word for receptivity, but his example shows the value he places on receptivity and a kind of open-mindedness. We could also call it intellectual humility, and he also indicates the high value he places on intellectual humility (2A8) when he praises the delight one can and should take when one's mistakes are corrected by another person. (Similarly, Confucius/Kongzi's "where three men are together, I can learn from one of them.")

${ }^{5}$ Oddly, there is no word for receptivity in the Chinese language, but in the West, where receptivity isn't as valued, we do at least have the word. The Chinese may not have the word, but their philosophizing and cultural practices demonstrate the value they place on receptivity, as per the striking example to be mentioned in the main text. 
By contrast, consider what Aristotle says about the virtuous individual. For Aristotle, such a person always acts rightly and knows what is right. So Aristotle never recommends, for example, that the virtuous person listen to those who disagree with him (it was always a him), that he learn from them, or that he happily admit ethical mistakes. He already, for Aristotle, knows everything he needs to know. Let's put it this way. For Mengzi (and Kongzi) ethical action requires us to take into account the (differing) point of view of others; but Aristotle never once says or implies this sort of thing about the virtuous individual - and of course and in consequence open-mindedness is not a virtue in Aristotle's intellectual armamentarium the way it is for present-day (supposedly) neo-Aristotelian virtue epistemologists. (Aristotle speaks of a virtue of pride, but never recommends intellectual or moral humility of the kind Mengzi clearly advocates.) In general, then, Chinese philosophy demonstrates more open-mindedness and a greater respect for open-mindedness than one finds in historical Western thought.

To summarize, I am saying that we philosophers should move into a future of internationalized or global philosophy with great attention to analytic distinction-making, with sensitivity to linguistic and psychological nuance, with an open-mindedness vis-à-vis those who disagree with us, but also and finally with confidence in and a large sense of the importance and powers of philosophy itself. Can we manage to do all this? I don't know, but I certainly hope we can. (The first appendix, however, may give us reason for skepticism about the open-mindedness part of the practical advice I have just offered.) But now it is time to move on to questions involving the relationship between psychology and philosophy, philosophical questions, that is, that more attention to certain aspects of psychology can help us clarify and even resolve. For the most part our discussion won't bring in comparisons between East and West, but will focus directly and persistently on purely philosophical issues-except those issues turn out to be not so pure because psychology is so relevant to our understanding of what they involve and to our ability to deal successfully with them. I will begin, in our next chapter, by speaking of the relevance of empathy to a whole host of philosophical issues. Empathy already played an important role in the discussion of moral sentiment and of its yin-yang basis in Chap. 2, but we are about to see that empathy is relevant to a much wider range of philosophical tasks or problems than Chap. 2 ever indicated. 
Open Access This chapter is licensed under the terms of the Creative Commons Attribution 4.0 International License (http://creativecommons.org/licenses/ by $/ 4.0 /)$, which permits use, sharing, adaptation, distribution and reproduction in any medium or format, as long as you give appropriate credit to the original author(s) and the source, provide a link to the Creative Commons licence and indicate if changes were made.

The images or other third party material in this chapter are included in the chapter's Creative Commons licence, unless indicated otherwise in a credit line to the material. If material is not included in the chapter's Creative Commons licence and your intended use is not permitted by statutory regulation or exceeds the permitted use, you will need to obtain permission directly from the copyright holder.

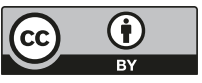

